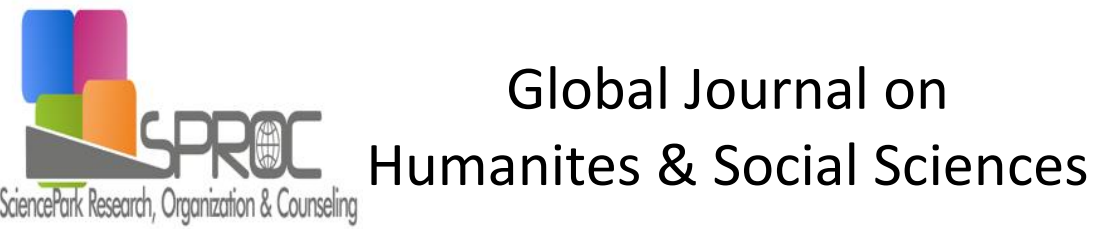

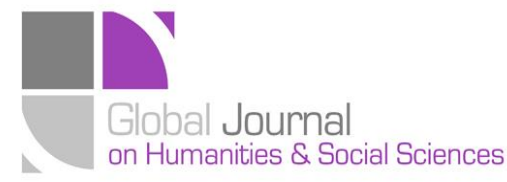

Vol 3 (2016) 397-409

Selected Paper of 4th World Conference on Design and Arts, (DAE-2015)

26-28 June 2015, St.Petersburg Christan University, St. Petersburg, Russia.

\section{Visual perception management in advertisements}

Seda Nur Atasoy*, Tortum Vocational High School, Design Department, Graphic Design Program, Atatürk University, Tortum, Erzurum 25430, Turkey.

\section{Suggested Citation:}

Atasoy, S., N. (2015). Visual perception management in advertisements,

A

[Online]. 03, pp 397-404. Available from: http://sproc.org/ojs/index.php/pntsbs

Received January 03, 2015; revised March 11, 2015; accepted May 06, 2015.

Selection and peer review under responsibility of Prof. Dr. Milan Matijevic.

(C2016 SciencePark Research, Organization \& Counseling. All rights reserved.

\begin{abstract}
The subconscious includes all mental events that stay out of conscious perception and have no potential to access to the level of conscious. In our present day, the conscious is one of the objects where the advertisers often use it to make hidden inducements in order to influence the behaviors of the consumers and where the desire to buy a product is created, placed in it to best market and publicize their own trademarks and products. When the consumer wants to buy a product, it is necessary that the product for which advertisement is made in the mind emerge. And, this makes us question the necessity of the visual perception management in the human brain. In daily life, thousands of information, pictures and sounds go to the memory on a daily basis, and the human brain recalls them if only they are necessary. For this reason, the advertisers develop their products with such kind of methods which could be recorded in their clients' memory for a long time.

Eighty percent of the perception is structured by the eyesight. The expert psychologists work together with the art directors within the companies where the hidden messages are produced, in order to place in the pictures such images which are to attract attention of the subconscious. Such images have certain qualities which trigger and actuate the visual perception. E.g: placing into the background the green color in order to make a product look more reddish.

This study includes the way of functioning of the visual perception in the advertisements together with the examples, and researches whether the attempts to actuate and induce the human feelings and motives could in fact control the behaviors and thoughts, and whether they are right ethically.
\end{abstract}

Keywords: visual perception management, advertisements, subconscious, tachistoscope, poetzle effect.

\footnotetext{
* ADDRESS FOR CORRESPONDENCE: Seda Nur, ATASOY, Tortum Vocational High School, Design Department, Graphic Design Program, Atatürk University, Tortum, Erzurum 25430, Turkey. sedanur.topaloglu@atauni.edu.tr /
}

Tel.: +90-442-761-2524 


\section{Introduction}

Advertisement can be expressed as a service which is created to draw attention of people to a specific product, to persuade them to perform a specific behavior, to direct them to a specific opinion or to give information on a situation. Nowadays in almost all stage of communication age which is rapidly developing and expanding, advertisement factors take place. As a result, we encounter cultural, social, economic and psychological impacts of advertisement inevitably and it has an impact in almost all fields of our lives (from film posters to television series, from newspapers to billboards, from web sites to the sector which gets into action before elections) against our will.

The main purpose of advertisements is the message which is given to have an impact on the target population and most of them are manufactures which have economic concern. Therefore, advertisements make people also buy products which they don't need other than ones they think they need them. Today, this has become a situation such that advertisements use some kind of secret hypnosis method by leading decision making processes of persons and by giving subliminal messages. Nomenclature

\section{Leading the Subconscious}

Sağlam defines conscious and subconscious as follows: conscious is an awareness act which becomes functional by the infant to receive some stimulations in the uterus and ends at last breath and as well as person's own personality, it is the whole of cerebrally understanding activities which enables the person to sense all material and nonmaterial existences and notions in external world. Subconscious, however, which is "covered", we are aware and which effects our conscious and our movements in practical life has also been named as; sleeping conscious, passive conscious and deep conscious. Subconscious is the weakest awareness situation. (1)

Subliminal or subconscious messages however, which we may define as a sign, symbol or message embedded in an object are under the limits of normal human perception and are designed not to be realized from the very start. Subliminal techniques are frequently being used in advertising field since 1950s. Mobile phones which characters in television series or films use, trademarks of drinks they drink, cars they use etc. are some of subliminal message examples. Matters of suitability of these technics which cannot be realized on conscious level however take place in subconscious, should be discussed from ethical perspective.

Theatre, television or advertisement films or any kind of television program becomes movable by 24 frames to be lined up sequential within one second. Human eye senses 24 frames in a second at anything it looks at and picks out the image by gathering them. However, when designing a theatre film, advertisement or any image, people who use the 25th frame may place secret messages in subconscious of people. Because our eye sees the 25th frame but does not sense it, consequently that frame only takes place in our subconscious. (2) Even the most conscious persons are not able to decode these messages at first sight. And this situation renders our societies defenseless against subliminal advertisement. 
In 1957, a marketing researcher whose name was James Vicary making market researches has used "subliminal advertisement" definition by determining that messages flashing very quickly on cinema screen have impacted consumption preferences of humans. In his research, Vicary has placed messages such as "drink Coca-Cola", "eat popcorn" between films by means of a device called as "tachistoscope". These messages were appearing in a short period such as 1/3000 of a second and were repeating once in each 5 seconds. After this film, an increase of $57.8 \%$ in popcorn sales and 18.1 $\%$ in Cola sales has been observed in New Jersey. (3)

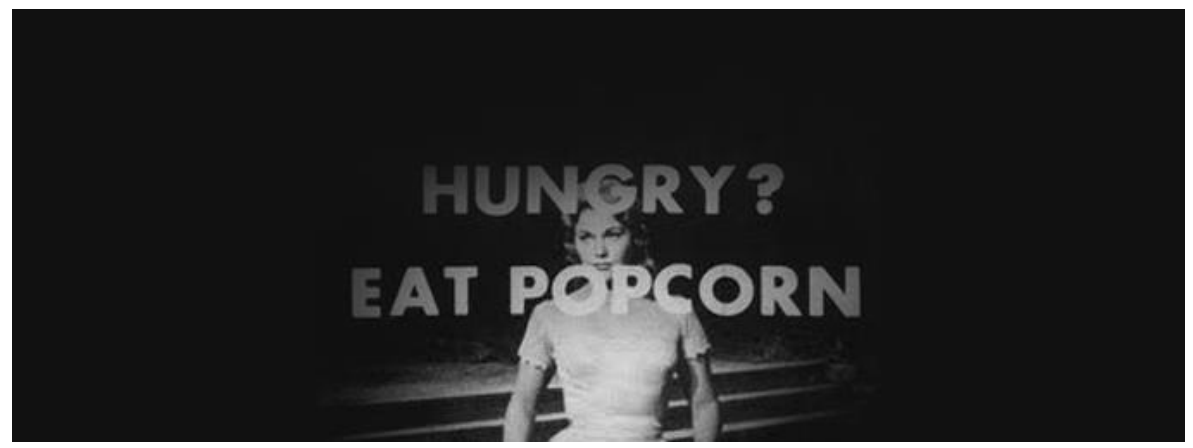

Figure 1. "Picnic(1955)" http://www.izgorenakademi.com/index.php/company-blog/item/360-dikkat-buyazida-bilincalti-mesaj-yoktur

Of even date, Vance Packard has investigated how quite a few emotions and motives were directed, sexuality and death being in the first place and how subliminal action shows its effect in his book called as "The Hidden Persuaders".

After a long time since publish of the book (in 1983) a survey assessing subliminal advertisement awareness of the public has been conducted and $81 \%$ of participants have stated that they have heard the concept of subliminal advertising. And most of participants have expressed that subliminal advertisements are against the ethics and harmful.

In presentation of advertisements placed in subconscious, individuals are aware which institution, product or trademark they are watching. However, they are not aware of reasons which direct them to choose that product, in other words images, objects, persons, voices and colors addressing their desires and fears hidden in their subconscious

There are various techniques with regards to subliminal marketing. These are: Tachistoscope, Poetzle Effect, Instant Effect, Embedding, Mirror Writing and ESP.

Tachistoscope, is a film projector designed by Dr. Samuel Renshaw which projects display or image by means of its shutter which open and close in a short period such as 1/3000 of one second. These displays are projected at each 5 seconds, however this period may prolong or shorten for various purposes and impacts. Tachistoscope which discloses on the screen words or images on a certain number in certain time intervals very quickly, nearly as lightning and operates with a similar technique to display of an image on a projection, operates with the principle of increasing the recognition speed in the mind by given images. It has been stated by some references that this device has provided basis for emergence of subliminal advertisements. 


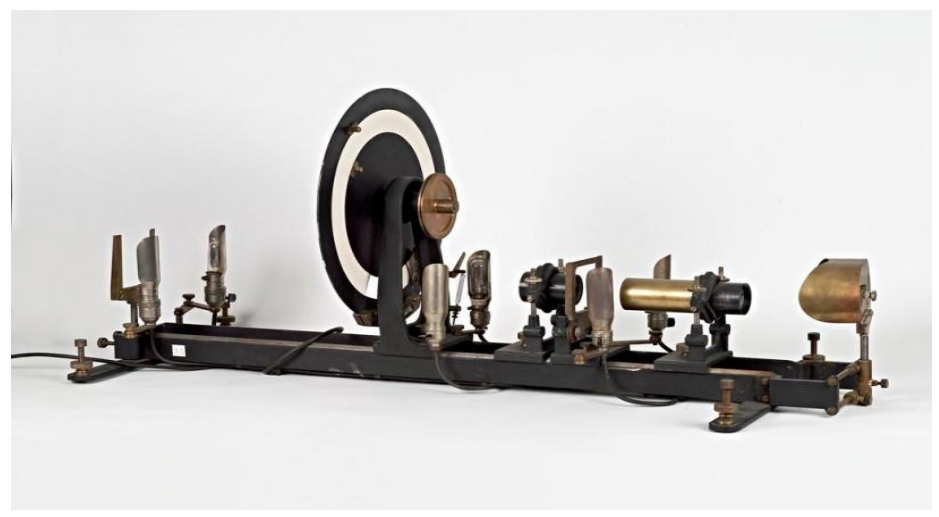

Figure 2. 'Tachistoscope device' http://tehet.net/kutuphane/takistoskop-tachiscope-cihazi-nedir/

Poetzle Effect (Delayed Effect), In 1917s, Dr. Poetzle has developed his own subliminal stimulation hypothesis by using Tachistoscope and hypnosis. In this hypothesis named as Poetzle Effect a delayed action is in question. Briefly previously acquired subliminal messages emerge days, weeks later when dreaming and thereafter come into action. When entering a shopping mall, an individual realizes the product and purchases the product even he doesn't need it since he has been stimulated.

Instant Effect As a result of secret message writing of James Vicary which he has performed in theatre in 1957 ('Are you hungry? Eat popcorn. Drink Coca Cola), persons to increase sales can be given as an example for instant effect.

Embedding, Placing Writing or Figure on Objects, is the situation of placing writing or figures which can be rarely realized by human eye, on printed or video advertisements. Directly aiming at subconscious, these messages are blended, associated and saved for later in the mind.

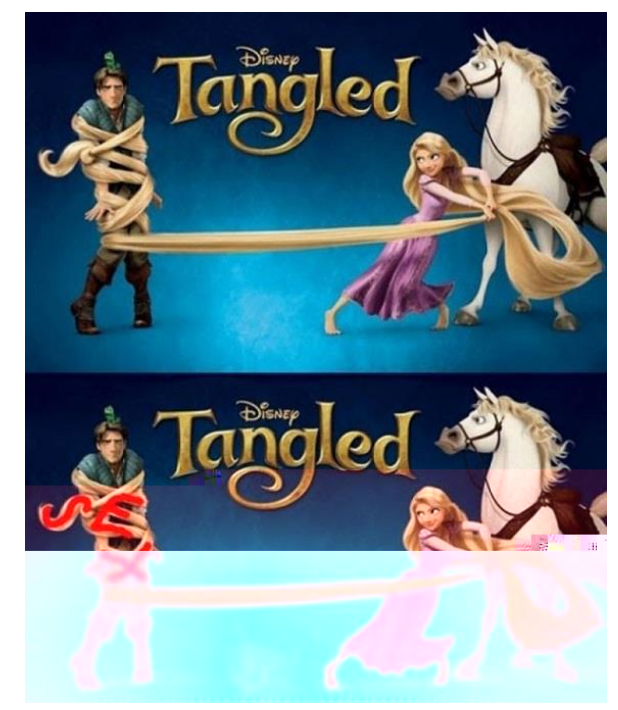

Figure 3. "Embeded Writing" http://www.wowmuseum.org/wp-content/uploads/2013/08/Disney-

Subliminal-Message-69.jpg 
Mirror Writings, The brain is so sensitive that it can process even mirror writings into subconscious. For instant, Bacardi Rum company, in its advertisements it gave Playboy, Time and Esquire magazines by spending 115.255 Dollar, it did not only give demonstration of the product but also called human subconscious for Bacardi Rum purchase by a writing it embedded into the picture. (4)

ESP, Extra Sensory Perception, means perception beyond senses, sixth sense, and instinct. Telepathy, power of seeing the future, foreknowledge and psychokinesis which we name as the gift of individual being able to affect a physical existence or event by thinking that particular thing are types which are example for this title.

\section{Tools which Activate Purchasing Motivations}

Tools which activate purchasing motivations are needs which are composed of stimulating impulses which activate the subconscious which the individual would not understand at first sight.

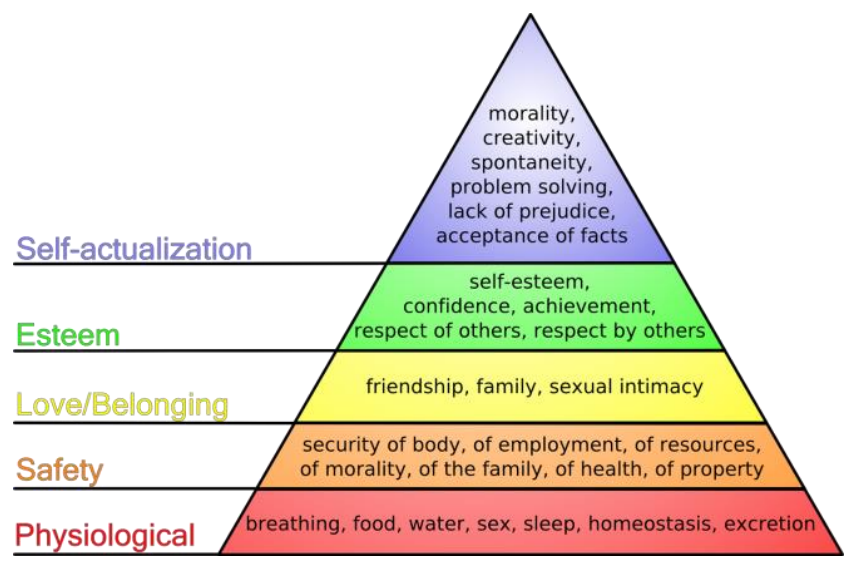

Figure 4. "Maslow's Hierarchy of Needs" http://dilancetin.com/2013/02/17/maslowun-kedisi/

Aforementioned physiological concepts constitute the basis of Maslow's hierarchy of needs. These needs which take place in the ground of the pyramid built by Maslow, are used for subliminal messages in advertisements and by this way, they take the attention of the subconscious and work as stimulator.

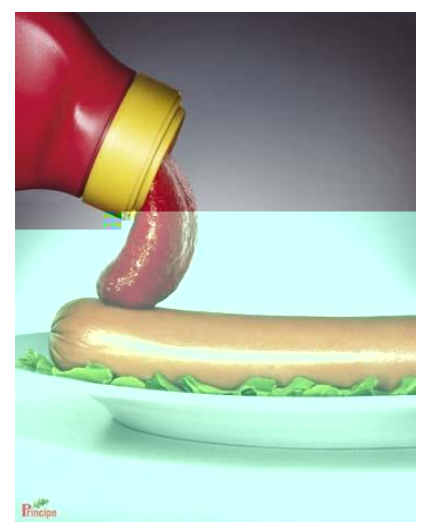

Figure 5. http://justcreative.com/2008/07/30/192-of-the-best-smart-clever-creative-advertisements/ 
According to Maslow, for an individual to come to the level of self-realization (morality, creativity, spontaneity, problem solving, lack of prejudice, acceptance of facts), it is required him to remove obstacles in front of him. When this situation is taken into account in subliminal advertisements in terms of the structure in our society, it can be said that the zenith point of the pyramid comes to the forefront more preponderantly.

Consumer behaviors plays an important role in terms of marketing in generation of trademark logos. Marketing staff and advertisers aim to reach their purpose by investigating creative and different methods continuously to affect consumers. In this respect, when we evaluate amazon.com, FedEx, Toblerone, Baskin-Robbins, F1 logos;

Amazon.com is the biggest shopping site which has been established as first. When its logo considered, it is the message that you can find many things in Amazon website delivered by Amazon trademark from ' $A$ ' to ' $Z$ ' in the orbit of yellow arrow. And also the smile created by the yellow arrow expresses that you will be satisfied with products you have bought.

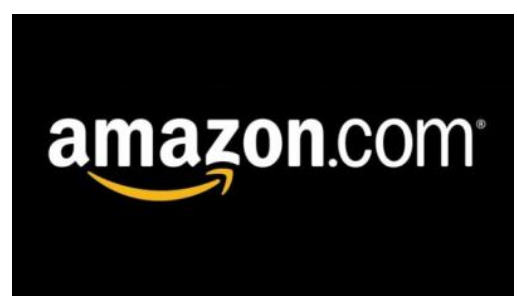

Figure 6. http://www.inspirationsweb.com/miscellaneous/great-brand-logos-hidden-messages

FedEx Corporation named organization is an American company which gives air-land transfer and logistics service world-wide. When FedEx logo is examined, letters which have been written firmly are seen. However, When " $E$ " and " $X$ " letters which have been written with orange-colored letters are looked carefully, an arrow shape which is directed to right side is seen. This arrow, at the same time tells consumers of the trademark that they deliver products rapidly and the delivery is performed to the right place.

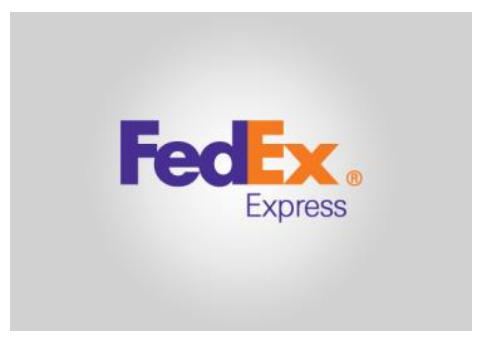

Figure 7. http://www.inspirationsweb.com/miscellaneous/great-brand-logos-hidden-messages/

Toblerone is a chocolate trademark which has been established by Theodor Tobler in 1908 in Switzerland. When you carefully look at the logo of Toblerone trademark, you see the picture of the bear which hid into Mattherhon Mountain. This also shows from where this chocolate trademark came from. Because Toblerone chocolate includes nougat, almond and honey as well as chocolate. 

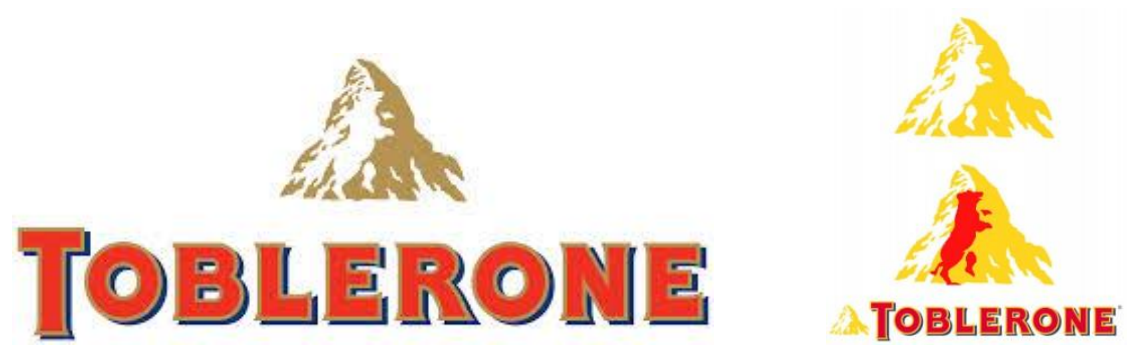

Figure 8. http://www.savourbeer.com/business/the-savour-logo/

Baskin-Robbins is an international ice-cream chain. When the section written with pink letters between $B$ and $R$ letters of the logo is looked, number of 31 is seen. Number of 31 represents 31 kind of ice cream this trademark manufactures.

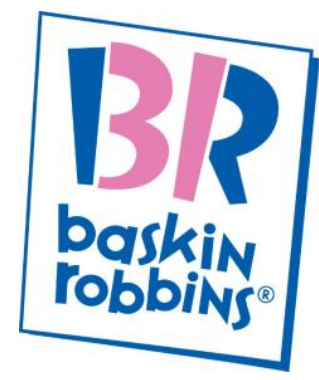

Figure 9. http://brandtalks.org/wp-content/uploads/baskin-robbins.jpg

The negative area which is in the middle of the logo tilted to the right side to create speed effect, creates number of 1 which cannot be realized by everyone at first sight. Under normal conditions, while number "one" is seen as red zone, the real "one" number is in the gap between F and Red flag.

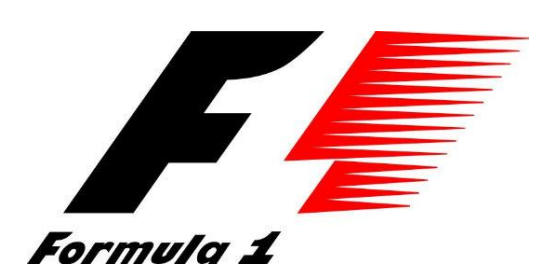

Figure 10. http://webdesignledger.com/inspiration/15-logos-with-hidden-messages

$L$

It is without doubt that colors, letters, symbols, writings and music are among most important factors in management of visual perceptions. Colors have certain responses in the subconscious of human and they definitely effect decision making of human. For instant, placing green color on background to show a product more red, or utilization of black when telling about the death etc. Opposite colors make the product look more vivid and active. Colors can also be used according to the meaning the product in the advertisement has. For example, such as preferring white to express 
cleaning of a detergent. A conducted research determined that blue and green particles put into a detergent give the opinion that it is more effective and clean from yellow and white only. Another example; the reason of colors of McDonald's company to be yellow and red is opinion of these two colors are the most appetizing colors in human brain. When logo of Sun Microsystems is evaluated in terms of subliminal type, it creates a perfect ambigram which can be read from every direction. There isn't single " $\mathrm{S}$ " letter in the logo. Layout of " $U$ " and "N" letters give "SUN" word.

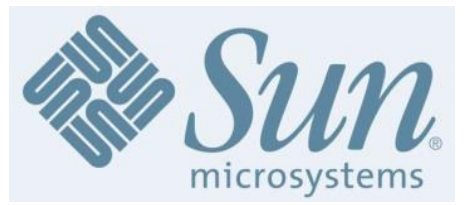

Figure 11. http://www.hurriyet.com.tr/pasaj/23281059.asp

3 "i" letters in the middle of the "families" word which means "aileler", are representing mother, father and child.

\section{Families}

Figure 12. http://www.hurriyet.com.tr/pasaj/23281059.asp

In the logo prepared for sushi restaurant, long edges of " $\mathrm{H}$ " letter create chopsticks.

$$
\operatorname{sus}|\cdot| 1
$$

Figure 13. http://www.hurriyet.com.tr/pasaj/23281059.asp

"up" word which means "yukarı" in Turkish, has been symbolized by " $U$ " letter which is created by the arrow symbol showing the upward and " $\mathrm{P}$ " letter hidden in the black area.

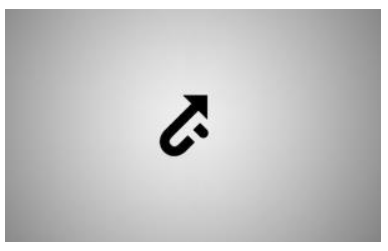

Figure 14. http://www.hurriyet.com.tr/pasaj/23281059.asp 
Atasoy, S., N. (2015). Visual perception management in advertisements, 404. Available from: 

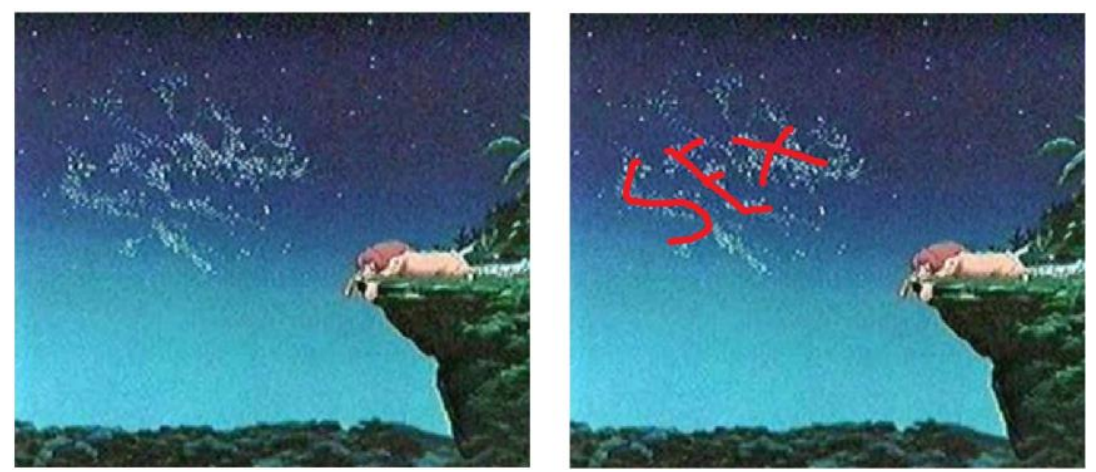

Figure 17. http://fc01.deviantart.net/fs71/f/2012/343/5/a/lion_king_subliminal message by alerkina2-

\section{d5njirm.jpg}

Another explicit example is the death's head which Salvador Dali created with 7 naked women, has been placed on the head part of the butterfly in the film poster of "The Silence of the Lambs".

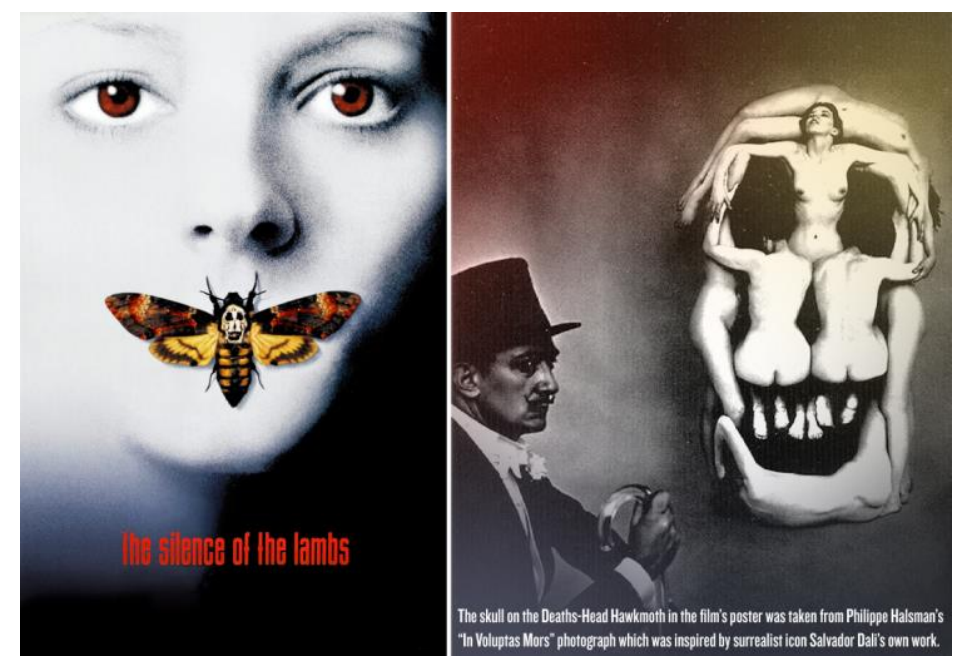

Figure 18. https://imbloodyibiza.files.wordpress.com/2013/09/o-silencio-dos-inocentes-poster.jpg

The sex expression in introduction poster of Burger King, has succeeded to give the same impression with different sexual association and key words. 


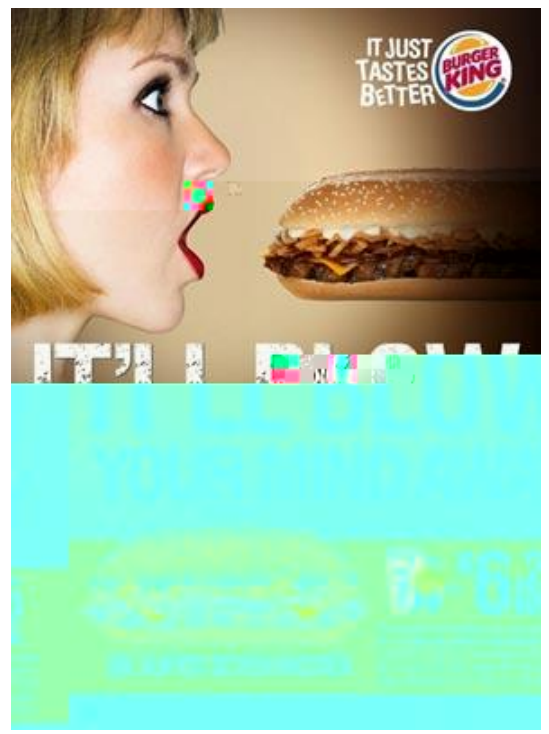

Figure 19. http://www.11points.com/Food-Drink/11 Hidden Messages In Food Ads and Logos

\section{Conclusion}

It has been concluded that advertisements which make reference to physiological stimulators to direct consumers' minds used by advertisers are not suitable in terms of ethics since they direct human behavior and thoughts involuntary. Thus, contents which consumption habits are secretly directed in our country have been prohibited with "Subliminal techniques can not be used in commercial communication" statement in accordance with 2nd clause of 9th article of Law on Establishment and Broadcast Services of Radio and Television with no. 6112 of TBMM acknowledged on February 15th, 2011(5). However, inspections and sanctions are not sufficient. Again in letter of Radio and Television Supreme Council, Directorate of Monitoring and Evaluation Department on April 24th, 2015 with no. 44096195-110.01.03/0837-5993; it has been set forth that the task of organizing and inspecting radio and television broadcasts has been assigned to Radio and Television Supreme Council with Law on Establishment and Broadcast Services of Radio and Television with no. 6112, however Radio and Television Supreme Council inspected programs after they are broadcasted in terms of compliance with related law provisions and it is not authorized to interfere programs before broadcasting or remove programs from broadcasting. In the same letter, a statement as "Although utilization of subliminal techniques is prohibited all over the world by laws, since it is not possible to make such determination by means of existing technologies, there is no routine workout in Supreme Council for determination of whether or not subliminal techniques are used in broadcasts. There isn't any determination with regards to contradiction to mentioned principle up to today and it has been notified that in case of determination of any issue against corresponding law, the required sanction will be implemented. However, it is possible to see already now negative results which will be caused by the truth that unfortunately there is no technology and experts in our country who will follow up this violation and impose a penalty 'although it is forbidden in the world'. This deep subliminal method started over advertisements poses a danger for minds of people not only from the point of advertisements but also from the point of also giving opportunity of allowing dictation of an opinion either political or something else. At the same time, mental development of children is put in risk by means of placed pornographic or illegal organizational symbols. 


\section{Acknowledgement}

I would like to endlessly thank my dear lecturer Prof. Dr. Incilay Yurdakul who has contributed this research and my family due to their support.

\section{Online License}

(2)

http://entellektuel.s4.bizhat.com/entellektuel-post-6808.html

bicimlendiriyor/

Figure 1. "Piknik(1955)" http://www.izgorenakademi.com/index.php/company-blog/item/360dikkat-bu-yazida-bilincalti-mesaj-yoktur

Figure 2. 'Takistoskop cihazı' http://tehet.net/kutuphane/takistoskop-tachiscope-cihazi-nedir/

Figure 3. "Gömme Yazı" http://www.wowmuseum.org/wp-

content/uploads/2013/08/Disney-Subliminal-Message-69.jpg

(4) $\quad$ http://dergi.kmu.edu.tr/userfiles/file/Mayis20141/23m.pdf

Figure 4. "Maslow'un ihtiyaçlar Hiyerarşisi" http://dilancetin.com/2013/02/17/maslowun-kedisi/

Figure 5. http://justcreative.com/2008/07/30/192-of-the-best-smart-clever-creativeadvertisements/

Figure 6. http://www.inspirationsweb.com/miscellaneous/great-brand-logos-hidden-messages

Figure 7. http://www.inspirationsweb.com/miscellaneous/great-brand-logos-hidden-messages/

Figure 8. http://www.savourbeer.com/business/the-savour-logo/

Figure 9. $\quad$ http://brandtalks.org/wp-content/uploads/baskin-robbins.jpg

Figure 10. http://webdesignledger.com/inspiration/15-logos-with-hidden-messages

Figure 11. http://www.hurriyet.com.tr/pasaj/23281059.asp

Figure 12. http://www.hurriyet.com.tr/pasaj/23281059.asp

Figure 13. http://www.hurriyet.com.tr/pasaj/23281059.asp

Figure 14. http://www.hurriyet.com.tr/pasaj/23281059.asp

Figure 15. http://www.hagerty.com/uploadedImages/Images/Articles/VW_ThinkSmall.jpg

Figure 16. https://tr.pinterest.com/pin/534661786982419234/

Figure17.

http://fc01.deviantart.net/fs71/f/2012/343/5/a/lion king subliminal message by alerkina2d5niirm.jpg

Figure 18. https://imbloodyibiza.files.wordpress.com/2013/09/o-silencio-dos-inocentes-poster.jpg Figure 19. http://www.11points.com/Food-Drink/11 Hidden Messages In Food Ads and Logos (5) http://www.mevzuat.gov.tr/MevzuatMetin/1.5.6112.pdf

\section{Suggested Online Resources}

https://www.youtube.com/watch?v=zdSisyamDSc (In this example, the video link is attached to the article as assets on April 10, 2015.) http://news.bbc.co.uk/2/hi/health/6427951.stm http://www.adlibilimler.net/content/g\%C3\%B6rsel-subliminal-bilin\%C3\%A7alti-mesajlar http://brandtalks.org/2013/08/subliminal-mesaj-ve-markalar/ http://safazengin.blogcu.com/reklam-ve-reklamciligin-hayatimizdaki-veri/5926112 http://tr.wikipedia.org/wiki/Reklam http://marketingland.com/secret-meanings-behind-40-brand-logos-109215 http://justcreative.com/2008/07/30/192-of-the-best-smart-clever-creative-advertisements/ http://tehet.net/kutuphane/takistoskop-tachiscope-cihazi-nedir/ http://dergi.kmu.edu.tr/userfiles/file/Mayis20141/23m.pdf 
http://www.truvainegi.com/2013/07/subliminal-mesajlar.html

\section{References}

Sağlam, M. (1997).

Istanbul: Denge Publications

\section{Suggested Reference}

ADVERTISING AGE, French Connection Takes "Subliminal" Approach, Crain Communications Inc., Chicago, 25 Şubat 1999

AYDEMIR, Mustafa / KMÜ Journal of Social and Economic Research 16 (Special Issue I): 166-170, 2014

BAUDRILLARD, Jean, Simülakrlar ve Simülasyon, DoğuBatı Publications, 2014

BENN, Alec, The 27 Comman Mistakes In Advertising, Amacom, New York, 1978

BAKER, Stephan, Visual Persuasion, National, New York, 1961

BUCHENROTH, Michael Leroy, Subliminal Advertising Effects in Magazine Advertisements, Master's

Thesis, B. S. The Ohio State University, Ohio, 1977

CHEREBUNI, George, Global Marketing, New York University, Advertising, Marketing, Sales and Promotional

Certificate Program Lecture Notes, 1999

ÇELiK, Metin, "Routing Consumer Advertising", Master Thesis - 2000 -i̇stanbul University.

DARICI, Sefer, Subliminal Advertising and Communication Techniques, Istanbul Development University /

Economics Series

DWEK, Steve, Marketing Principles and Practices, New York University, Advertising, Marketing, Sales and

Promotional Certificate Program Lecture Notes, June 1999

FAVRE, Jean-Poul and NOVEMBER, Andre, Color and Communication, ABC Verlag, Zerach, 1979

FREITAG, E. F. \& ZACHARIAS C. (2002). Power of Your Thoughts. (Trans.: Gülderen Pamir). İstanbul: O Omega

Publications.

HANNIBAL, Ed, Advertising: Understanding How It Works, New York University, Advertising, Marketing, Sales and Promotional Certificate Program Lecture Notes, June 1999

HIGGENS, Tony, Advertising, Sundrive, Atlanta, 1987

GUTENBERG, Adam, Marketing Strategies of McDonald's, Bell Pub., New York, 1985

GÜLERCE, Aydan, Introduction to Psychology: impulse and motivation, Hacettepe University, Department of Psychology Publications, Ankara, 1991

GÜZ Nükhet ve KÜÇÜKERDOGAN R. 2005 - "Istanbul Kultur University Diary", in, indicators spheres, Advertising And the "other" Concept of Social Sciences and Art, Volume 3, Issue 1.

JOHNSON, Hillary, Marketing, New Way, Boston,1994

MCVEY, G.F., Putting Color in to Your Visual Presentation, Photomethods, Boston, 1976.

MESSARIS, P. (1997). Visual Persuasion. The Role of Images in Advertising. USA: Sage Publications.

MURPHY, J. (1963). The Power of Your Subconcious Mind. USA: Prentice Hall Inc.

OLSON, Jerry \& SENTIS, Keith, Advertising and Consumer Psychology, Praeger, New York, 1985

ÖZKAN, Z. (2002). The Power of Awareness. Istanbul: Life Publishing PACKARD, V. (2007).

PACKARD, Vance, The Hidden Persuaders, David McKay Company Inc., New York, 1957

PERCY, L., \& ROSSITER, J.R., Advertising and Promotion Management, McGraw-Hill, New York, 1987

SOMER, Robert, The Mind's Eye, Delacorte, New York, 1978

SPRINGER, S. P., Left Brain, Right Brain, W. H. Freeman, New York, 1989

ROMTIN, H., Subliminal Messages, Term Project, Hazel McCallion, Senior Public School, Canada, 1991

WEIR, White, Another Look At Subliminal "Facts", Advertising Age, Crain Communications Inc., Chicago, 15 November 1984

ZAR, Murat, McDonald's, Monclair State University, Master of Business Administration Term Project (Unpublished), New Jersey, April 1999. 